\title{
KOMBINASI TEKNIK KONSERVASI TANAH DAN PENGARUHNYA TERHADAP HASIL JAGUNG DAN EROSI TANAH PADA LAHAN KERING DI SUB DAS BIYONGA KABUPATEN GORONTALO
}

\author{
Combination of Soil Conservation Techniques and Its Effect on the \\ Yield of Maize and Soil Erosion of Dry Land in \\ Biyonga Sub-Watershed, Gorontalo
}

\author{
Nurdin \\ Program Agroteknologi, Fakultas Pertanian \\ Universitas Negeri Gorontalo \\ JI. Jend Sudirman 6 Kota Gorontalo 96122 \\ E-mail: nurdin@ung.ac.id
}

Diterima: 3 April 2012; Direvisi: 13 April 2012; Disetujui: 24 April 2012

\begin{abstract}
Upland is one of land potentials for maize development, but most farmers were using upland without soil conservation, so the soil erosion is difficult controlling and productivity is decreasing. This research was aimed to find of soil conservation technique combinations which can minimize soil erosion and rising of maize yields. This research was carried out in Biyonga Sub-Watershed of Gorontalo Regency. Experimental was conducted in afactorial random block design with2 main factors, where first factor was contour cultivation and the second was strip cropping which each factors consisted of 5 treatments for manure and mulching with 3 replicates. Erosion box and their soil collector were used to measure of soil erosion. Results showed that contour cultivation is \pm 1.24 higher than strip cropping toincrease maize yields, but soil erosion was \pm 1.20 higher than strip cropping. The highest of maize yield was 5.82 ha $^{-1}$ tahun $^{-1}$ and their soil erosion was 1.34 ton ha-1 tahun ${ }^{-1}$. Soil erosion on the strip cropping was only 1.08 tonha $^{-1}$ tahun $^{-1}$ although maize yields were only 4.80 ton ha ${ }^{-1}$. The best dosage for manure and mulching were 10 ton ha-1 and 12 ton ha-1.
\end{abstract}

Keywords: erosion, strip, cropping, upland, maize

\begin{abstract}
Abstrak
Lahan kering merupakan salah satu lahan yang potensial untuk pengembangan jagung, tetapi umumnya petani jagung menggunakannya tanpa menerapkan teknik konservasi tanah, sehingga erosi tanah sukar dikendalikan dan produktifitasnya menurun. Penelitian ini bertujuan untuk mendapatkan kombinasi teknik konservasi tanah yang dapat menekan erosi tanah dan meningkatkan hasil jagung. Penelitian ini dilaksanakan di Sub DAS Biyonga Kabupaten Gorontalo. Rancangan penelitian menggunakan rancangan acak kelompok faktorial dengan dua factor, yaitu faktor pertama penanaman menurut kontur dan faktor kedua penanaman dalam strip yang masing-masing faktor terdiri dari lima perlakuan pupuk kandang dan mulsa serta masing-masing tiga ulangan. Pengukuran erosi tanah menggunakan petak erosi beserta drum penampung sedimen. Hasil penelitian menunjukkan bahwa penanaman menurut kontur meningkatkan hasil jagung sebanyak $\pm 1,24$ kali lebih banyak dibanding penanaman dalam strip, tetapi erosi tanah sebanyak $\pm 1,20$ kali lebih banyak dibanding penanaman dalam strip. Hasil jagung tertinggi sebanyak 5,82 ton ha-1 dan erosi tanah sebanyak 1,34 ton ha $^{-1}$ tahun $^{-1}$. Sementara, erosi tanah pada penanaman dalam strip hanya 1,08 ton ha-1 tahun $^{-1}$ dengan hasil jagung sebanyak 4,80 ton ha-1. Dosis pupuk kandang terbaikadalah 10 ton ha-1, sementara untuk mulsa adalah 12 ton ha-1.
\end{abstract}

Kata Kunci: erosi, strip, pertanaman, lahan kering, jagung 


\section{PENDAHULUAN}

Gorontalo dikenal sebagai provinsi Agropolitan yang menetapkan jagung sebagai entry point program tersebut. Produksi jagung provinsi ini dengan program Agropolitan terus mengalami peningkatan dari 130.251 ton tahun 2002 menjadi 572.874 ton pada tahun 2007. Pada tahun 2008 produksi ini diharapkan mencapai 1 juta ton [1]. Hasil tersebut dicapai setelah petani memperoleh bantuan dana untuk biaya usahatani jagung.Upaya peningkatan produksi jagung terus digalakkan melalui program intensifikasi, ekstensifikasi, agroindustri jagung, penguatan kelembagaan dan tata niaga (Ismail 2003). Namun, upaya pengembangan pertanian tanpa konsep yang jelas, hanya akan membuat program tersebut tidak berjalan terarah dan berkesinambungan. Salah satu upaya dalam program intensifikasi adalah optimalisasi produktifitas lahan kering di daerah aliran sungai (DAS)yang selama ini dibudidayakan untukjagung.

Luas lahan kering di Provinsi Gorontalo mencapai $437.597,59$ ha [1] atau $36 \%$ dari luas total provinsi yang potensial untuk pengembangan jagung. Hal ini sejalan dengan pernyataan Abdurachman et al. (2008) [2] bahwa lahan kering merupakan salah satu agroekosistem yang potensial untuk usaha pertanian, baik tanaman pangan, hortikultura maupun tanaman tahunan dan peternakan. Rukmana (2001) [3] mendefinisikan lahan kering sebagai sebidang lahan yang digunakan untuk usaha pertanian dengan menggunakan air secara terbatas, dan biasanya tergantung dari air hujan. Lebih lanjut Abdurachman et al. (2008) [2] menyatakan bahwa keterbatasan air pada lahan kering mengakibatkan usaha tani tidak dapat dilakukan sepanjang tahun, dengan indeks pertanaman kurang dari 1,50. Penyebabnya antara lain adalah distribusi dan pola hujan yang fluktuatif, baik secara spasial maupun temporal. Secaraalamiah, lahan kering juga peka terhadap erosi terutama bila keadaan tanahnya miring dan tidak tertutup vegetasi [19, 21], tingkat kesuburan tanahnya rendah, baik kandungan unsur hara, bahan organik, pH dan KTK $[4,7,3]$.

Melihat kondisi di atas, usahatani jagung di daerah ini memiliki faktor pembatas agroklimat dan lahan. Pada musim kemarau, lahan kering sukar untuk diusahakan karena keterbatasan lengas tanah yang tersimpan dalam jeluk matriks tanah sehingga jagung sulit berproduksi secara optimal. Pada musim penghujan bahaya erosi dan tanah longsor sering terjadi akibat ulah manusia membuka hutan dan mengalihfungsikannya menjadi lahan-lahan pertanian. Lahan dengan kelerengan di atas $8 \%$ peka terhadap erosi dan tanah longsor. Hal ini diperparah dengan pengolahan tanah yang intensif, mengakibatkan kerusakan tanah, erosi dan kehilangan air [3]. Pengolahan tanah intensif dapat menyebabkan kerusakan struktur tanah, menurunkan kapasitas infiltrasi tanah, dan daya hantar air (9), dan kualitas kimia serta biologi tanah [10]. Untuk mengurangi dampak tersebut, dianjurkan pengolahan tanah minimum $[11,12]$. Pengolahan tanah ini akan meningkatkan jumlah pori makro, sehingga meningkatkan kapasitas infiltrasi [13, 14], mengurangi aliran permukaan (run off) dan erosi tanah [15]. Namun, tindakan membatasi pengolahan tanah sering berakibat merosotnya produksi pertanian. Di samping itu, banyak petani yang membudidayakan jagung pada lahan kering berlereng tanpa tindakan konservasi tanah, sehingga terjadi erosi tanah dan berdampak pada keberlanjutan usahatani jagung. Penelitian ini bertujuan untuk memperoleh paket teknologi konservasi tanah yang dapat menekan erosi tanah dan meningkatkan hasil jagung sebagai komoditas unggulan Program Agropolitan.

\section{BAHAN DAN METODE}

Penelitian ini dilaksanakan dalam kawasan Sub DAS Biyonga yang merupakan salah satu anak DAS Limboto dan termasuk bagian dari Satuan Wilayah Pengelolaan Daerah Aliran Sungai (SWP-DAS) Bone Bolango serta masuk DAS Prioritas. Secara administratif, lokasi penelitian termasuk dalam Kelurahan Biyonga Kecamatan Limboto Kabupaten Gorontalo Provinsi Gorontalo. Sedangkan secara geografis, lokasi penelitian terletak pada 00030' LU sampai 00o40' LU dan 122o50' BT sampai 123000' BT. Penelitian dilaksanakan selama enam bulan, dari Februari sampai Agustus 2007.

Bahan penelitian terdiri atas: pupuk majemuk NPK Ponska (15-15-15) sebagai starter, pupuk kandang, mulsa jerami padi, benih jagung Lamuru FM dan strip rumput gajah (elephant grass). Penelitian ini menggunakan rancangan acak kelompok faktorial (RAKF) dengan perlakuan faktor utama berupa teknik konservasitanah (penanaman menurut kontur $(\mathrm{K})$ dan penanaman dalam strip (S)), lima faktor perlakuan pupuk kandangterdiri dari: perlakuan kontrol atau P0 (0 ton ha-1), P1 (2,5 ton ha-1), P2 (5 tonha-1), P3 (7,5 ton ha-1) dan P4 (10 ton ha-1). Sementara itu,limafaktor perlakuan pemulsaan terdiri dari: perlakuankontrol atau M0 (0 ton ha-1), M1 (3 ton ha-1), M2 (6 ton ha-1), M3 (9 ton ha-1), dan M4 (12 ton ha-1).

Sebelum pengolahan tanah dilakukan, sampel tanah diambil dari lahan dengan metodediagonal[17], padalima titik untuk keperluan analisis tanah di laboratorium.Pengambilan contoh tanah tidak terusik menggunakan ring sampel. Sementara untuk tanah terusik digunakan kantong plastik dengan kedalaman tanah $20 \mathrm{~cm}$. 
Analisis sifat fisik dan kimia tanah dilakukan untuk mendapatkan gambaran sifat tanah di lokasi penelitian. Pengolahan tanah dilakukan sebanyak tiga kali, kemudian dibuat alur-alur penanaman jagung menurut kontur dan strip. Pembuatan alur -alur strip untuk rumput gajah dengan jarak tanam $30 \mathrm{~cm}$ dan meratakan pupuk kandang. Pada alur strip dibuat saluran air yang memotong lereng dengan ukuran selebar 0,3 m dan sedalam 0,3 $\mathrm{m}$. Sebelum penanaman, dilakukan pencampuran pupuk kandang sesuai dosis perlakuan dengan tanah olah. Pupuk kandang berasal dari kotoran kuda yang telah diinkubasi selama \pm tiga bulan.

Penanaman dilakukan dengan cara ditugal dimana jarak tanam adalah $75 \mathrm{~cm} \times 75 \mathrm{~cm}$. Setiap lubang akan diisi 3 biji jagung dengan kedalaman $5 \mathrm{~cm}$. Pemeliharaan jagung meliputi penyulaman pada 7 hari setelah tanam (HST), penjarangan $14 \mathrm{HST}$, penyiangan $10 \mathrm{HST}$ untuk memberantas gulma, dan pembumbunan 28 HST untuk memperkokoh batang dan memperbaiki drainase. Pengendalian hama dan penyakit tidak dilakukan karena tanaman bebas dari gangguan hama dan penyakit. Selama penelitian berlangsung tidak terjadi hujan. Oleh karena itu dilakukan penyiraman sebanyak dua kali, yaitu pada awal tanam dan pada saat berbunga betina. Penyiraman menggunakan air yang ditampung dalam tong dan dihubungkan dengan selang.

Penilaian produktivitas jagung berdasarkan parameter hasil jagung kadar air 15\%. Seluruh data yang diperoleh dianalisis dengan sidik ragam pola rancangan acak kelompok faktorial (RAKF). Uji lanjut menggunakan uji beda nyata terkecil (BNT) pada taraf uji 5\% dengan Minitab versi 14.

Pengukuran erosi dengan metode petak erosi kecil, yaitu membuat petak erosi dengan panjang $22 \mathrm{~m}$, lebar $2 \mathrm{~m}$ dan tinggi 0,5 m [1], karena tanaman peraga adalah tanaman semusim (jagung). Disamping itu, dibuat bak penampungan (soil collector) dengan ukuran panjang $2 \mathrm{~m}$, lebar $0,5 \mathrm{~m}$ dan tinggi $0,5 \mathrm{~m}$., juga lubang pengeluaran aliran permukaan sebanyak 5 buah dengan jarak antar pipa $10 \mathrm{~cm}$ dan lubang di tengah dimasuki pipa plastik. Drum penampungan aliran permukaan ditanam sebagian (masuk ke dalam tanah) serta tutup drum. Perhitungan besar erosi dan aliran permukaan dilaksanakan menurut teknik yang diungkapkan Sofiah (1978). Untuk menghitung aliran permukaan digunakan persamaan sebagai berikut:

Total volume $=$ volume $1+$ volume 2 , dimana: VT = volume total aliran permukaan, volume 1 = volume air pada ember 1 dan volume 2 = volume air pada ember 2, sedangkan untuk menghitung total tanah yang tererosidengan menghitung berat tanah yang tertampung diambil cuplikannya sebanyak 1 liter, kemudian dihitung dengan menggunakan persamaan: $\mathrm{D} 1=(\mathrm{x} 1 \mathrm{~g} / 1 \mathrm{I}) \mathrm{x}$ volume air D1.......(3)

$\mathrm{D} 2=(\mathrm{x} 1 \mathrm{~g} / 1 \mathrm{l}) \mathrm{x}$ volume air D2.......(4)

$A=D 1+D 2$

Dimana: $A=$ erosi tanah (ton ha-1 tahun-1); D1 = tanah tererosi pada ember 1; D2 = tanah tererosi pada ember $2 ; \mathrm{x} 1=$ berat tanah kering oven pada ember $1 ; \mathrm{x} 2=$ berat tanah kering oven pada ember 2.Sebagai pembanding, maka dilakukan pendugaan besarnya erosi tanah dilakukan dengan metode USLE (universal soil loss equation) yang dikemukakan oleh Weischmeier dan Smith (1978), yaitu:

$A=R K L S C P$

Dimana: $A$ = banyak tanah tererosi (ton ha-1 tahun-1); $\mathrm{R}=$ faktor curah hujan dan aliran permukaan; $K$ = faktor erodibilitas tanah; $L$ = faktor panjang lereng; $\mathrm{S}=$ faktor kecuraman lereng; $\mathrm{C}=$ faktor vegetasi penutup tanah dan pengelolaan tanaman; dan $\mathrm{P}=$ faktor tindakan khusus konservasi tanah. Sedangkan faktor erodibilitas (K) dihitung dengan persamaan berikut:

$$
\begin{aligned}
& 100 K=1,292\left[2,1 M^{1.14}\left(10^{-4}\right)(12-a)+\right. \\
& 3,25(b-2)+2,5(c-3)] \ldots \ldots \ldots \ldots
\end{aligned}
$$

Dimana: $\mathrm{M}=\%$ pasir dan debu ( $\Phi$ 0,1-0,05 dan 0,05-0,02 mm); $a=\%$ bahan organik; $b=$ kode struktur tanah; dan $\mathrm{c}=$ kelas permeabilitas tanah.

\section{HASIL DAN PEMBAHASAN}

\subsection{Sifat-Sifat Tanah}

Tanah di lokasi penelitian bertekstur lempung berdebu, permeabilitasnya agak cepat, porositas tanah sedikit dan struktur gumpal bersudut (Tabel 1). Permeabilitas tanah yang agak cepat disebabkan karena tekturnya lempung berdebu dengan persentase pasirnya $36,15 \%$ walaupun porositas tanahnya relatif sedikit.Kadar $\mathrm{N}$ total, $\mathrm{P}$ dan $\mathrm{K}$ terekstrak Bray 1 sangat rendah, serta kadar $\mathrm{C}-O r g a n i k$ sedang. Kondisi $\mathrm{pH}$ tanah yang relatif netral $(6,71)$ menunjukkan bahwa tanah ini sebenarnya cukup menyediakan unsur hara yang esensial untuk tanaman.Sedangkan kapasitas tukar kation (KTK) tergolong sangat tinggi, sehingga tanah tersebut mampu memegang hara yang diberikan ke dalam tanah [20]. Berdasarkan kriteria sifat kimia tanah, maka status kesuburan tanah di lokasi penelitian tergolong sedang[32].

Status kesuburan tanah yang rendah, membutuhkan upaya strategis untuk meningkatkan kesuburan tanah agar dapat menyuplai kebutuhan hara bagi tanaman. Hal ini disebabkan oleh erosi yang mengakut hara dari lapisan olah. Pada endapan cekungan lahan di lokasi penelitian, terlihat gulma dan rerumputan 
tumbuh subur. Morgan (1986) menyatakan bahwa toleransi kehilangan tanah terjadi jika tingkat kesuburan tanah dapat dipertahankan 20 sampai 25 tahun. Soepardi (1983) melaporkan bahwa kehilangan unsur hara karena erosi selama dua tahun di Missouri, yaitu: $66 \mathrm{~kg} \mathrm{~N}$ ha-1, $41 \mathrm{~kg}$ P2O5 ha-1, 729 kg K2O ha-1, 309 kg CaO ha1, 145 kg MgO ha-1, dan 42 kg SO4 ha-1.Di samping itu, intensifnya pengolahan tanah dan penanaman pada musim tanam sebelumnya telah menyebabkan kehilangan unsur hara, baik karena hilang bersama panen, pencucian hara bersama air perkolasi dan penguapan karena proses volatilisasi beberapa unsur hara yang mobil, seperti NO3-, dan $\mathrm{NH} 4+$.Hasil wawancara dengan petani diperoleh informasi bahwa selama mengusahakan lahan tersebut untuk berbagai tanaman, belum pernah diberikan pupuk atau bahan organik, sehingga wajar bila di dalam tanah ketersediaan $\mathrm{N}, \mathrm{P}$ dan $\mathrm{K}$ sangat rendah.

Kemiringan lereng daerah penelitian sebesar 8\% atau landai sehingga cocok untuk diterapkan teknik konservasi tanah dengan metode vegetatif. Metode vegetatif yang cocok dan sesuai diantaranya adalah penanaman menurut kontur (countur cultivation) dan penanaman dalam strip (strip cropping). Hal ini sejalan dengan pernyataan Joseph (2005) bahwa lahan dengan kedalaman afektif lebih dari $30 \mathrm{~cm}$ dari permukaan tanah dan kemiringan lereng $8 \%$ $-25 \%$ sebaiknya diterapkan teknik penanaman menurut kontur. Teknik ini cukup layak diterapkan karena kedalaman efektif tanah rata-rata $37 \mathrm{~cm}$.

\subsection{Pengaruh Kombinasi Teknik Konservasi Tanah terhadap Hasil Jagung}

Penerapan teknik konservasi tanah pada lahan kering di Sub DAS Biyonga meningkatkan hasil jagung, kecuali pada perlakuan penanaman dalam strip (Tabel 2). Pada penanaman menurut kontur, taraf pupuk kandang dan mulsa nyata meningkatkan hasil jagung dengan hasil tertinggi (5,03 dan 4,99 ton ha-1) masing-masing pada taraf pupuk kandang 10 ton ha-1dan 12 ton ha-1. Berdasarkan kombinasi perlakuan, maka taraf pupuk kandang 10 ton ha-1 dan mulsa 12 ton ha-1 nyata meningkatkan hasil jagung. Hal ini disebabkan oleh pupuk kandang yang digunakan telah diinkubasi sehingga kandungan $\mathrm{C} / \mathrm{N}$ rationya rendah. Rasio $\mathrm{C} / \mathrm{N}$ rendah menghambat terjadinya imobilisasi oleh mikroba tanah[39, 11], sehingga pupuk yang diberikan terutama Phonska (N15-P15-K15) siap diserap oleh tanaman. Hasil penelitian Hudson (1971) menunjukkan bahwa pemupukan N15-P15-K15 sebanyak $250 \mathrm{~kg}$ ha-1 ternyata memberikan perlindungan tanah dengan hasil jagung 4,08 ton ha-1. Nurdin (2005) melaporkan bahwa pemupukan Phonska pada taraf $250 \mathrm{~kg}$ ha-1 nyata meningkatkan hasil jagung di Moodu Kota Gorontalo. Mulsa yang digunakan pada penelitian ini merupakan jerami padi. Neneng (2006) melaporkan bahwa mulsa jerami menghasilkan jagung pipilan kering lebih tinggi dibanding pupuk hijau, tetapi pengaruhnya tidak nyata. Mulsa jerami dapat menekan pertumbuhan gulma dan lebih memperkaya bahan organik tanah, mengawetkan bahan organik serta menurunkan suhu tanah [37] karena kadar C-organik di lokasi penelitian tergolong sangat rendah (Tabel 1). Nursyamsi et al. 2002 [25] menyatakan bahwa tanah yang memiliki kandungan C-organik <2\% memerlukan tambahan bahan organik sebanyak 5 ton ha-1. Sementara itu, Kamagi (1998) menyatakan bahwa pupuk kandang nyata meningkatkan hasil jagung. Hal ini didukung hasil penelitian Faesal et al. 2006 [17] bahwa taraf pupuk kandang 3 ton ha-1 nyata meningkatkan hasil jagung di Gowa Sulawesi Selatan. Pada penelitian ini, taraf pupuk kandang 2,5 ton ha-1 sudah nyata meningkatkan hasil jagung.

Tabel 1. Sifat-Sifat Tanah pada lapisan olah $(0-20 \mathrm{~cm})$ sebelum percobaan $(0-20 \mathrm{~cm})$

\begin{tabular}{|c|c|c|}
\hline Sifat Fisik/Kimia Tanah & Nilai & Kriteria/Kelas \\
\hline \multicolumn{3}{|l|}{ Tekstur : } \\
\hline Pasir (\%) & 36,15 & Lempung Berdebu \\
\hline Debu (\%) & 49,41 & \\
\hline Liat (\%) & 14,44 & \\
\hline Permeabilitas $\left(\mathrm{cm} \mathrm{jam}^{-1}\right)$ & 11,05 & Agar Cepat \\
\hline Pori-Pori Tanah & & Sedikit \\
\hline Kemantapan Agregat & & Sedang \\
\hline Struktur & & Gumpal Bersudut \\
\hline Berat Jenis $\left(\mathrm{g} \mathrm{cm}^{-3}\right)$ & 2,08 & \\
\hline Berat Volume $\left(\mathrm{g} \mathrm{cm}^{-3}\right)$ & 1,79 & \\
\hline \multicolumn{3}{|l|}{ Kadar Air $(\theta)$ : } \\
\hline $\mathrm{pF} O(\%)$ & 22,07 & \\
\hline pF $2,54(\%)$ & 20,31 & \\
\hline \multicolumn{3}{|l|}{$\mathrm{pH}$ : } \\
\hline $\mathrm{H}_{2} \mathrm{O}$ & 6,71 & Netral \\
\hline $\mathrm{KCl}$ & 5,82 & Masam Sedang \\
\hline C-Organik (\%) & 2,44 & Sedang \\
\hline $\mathrm{N}$ total Kjedahl (\%) & 0,05 & Sangat Rendah \\
\hline PBray 1 (ppm) & 8,23 & Sangat Rendah \\
\hline K Bray $1\left(\right.$ me $^{\left.100 \mathrm{~g}^{-1}\right)}$ & 3,06 & Sangat Rendah \\
\hline $\mathrm{KTK} \mathrm{NH}_{4} \mathrm{OAc}\left(\mathrm{me}^{\left.100 \mathrm{~g}^{-1}\right)}\right.$ & 51,11 & Sangat Tinggi \\
\hline
\end{tabular}


Tabel 2. Rataan hasil jagung akibat penerapan teknik konservasi tanah

\begin{tabular}{|c|c|c|}
\hline \multirow{2}{*}{ Teknik Konservasi Tanah } & \multicolumn{2}{|l|}{ Hasil Jagung (ton ha ${ }^{-1}$ ) } \\
\hline & Penanaman dalam Kontur & Penanaman dalam Strip \\
\hline \multicolumn{3}{|l|}{ Taraf Pupuk Kandang: } \\
\hline 0 ton ha $^{-1}$ & $2,58 a$ & $2,66 a$ \\
\hline 2,5 ton ha ${ }^{-1}$ & $3,67 b$ & $3,48 b$ \\
\hline 5 ton ha ${ }^{-1}$ & $4,71 \mathrm{c}$ & $3,46 \mathrm{~b}$ \\
\hline 7,5 ton ha $^{-1}$ & $4,82 d$ & $3,31 b$ \\
\hline 10 ton ha ${ }^{-1}$ & $5,03 e$ & $3,91 b$ \\
\hline \multicolumn{3}{|l|}{ Taraf Mulsa: } \\
\hline 0 ton ha ${ }^{-1}$ & $3,52 a$ & $2,60 a$ \\
\hline 3 ton $\mathrm{ha}^{-1}$ & $3,88 \mathrm{ab}$ & $2,95 b$ \\
\hline 6 ton ha $^{-1}$ & $4,09 b$ & $3,41 b$ \\
\hline 9 ton $\mathrm{ha}^{-1}$ & $4,33 b$ & $3,72 \mathrm{c}$ \\
\hline 12 ton $\mathrm{ha}^{-1}$ & $4,99 \mathrm{bc}$ & $4,15 d$ \\
\hline \multicolumn{3}{|c|}{ Kombinasi Pupuk Kandang+Mulsa: } \\
\hline 1 ton ha ${ }^{-1}+0$ ton $\mathrm{ha}^{-1}$ & $2,70 a$ & $2,29^{\text {tn }}$ \\
\hline 0 ton ha ${ }^{-1}+3$ ton ha ${ }^{-1}$ & $2,25 a$ & 2,23 \\
\hline 0 ton ha ${ }^{-1}+6$ ton ha $^{-1}$ & $2,39 a$ & 3,09 \\
\hline 0 ton ha ${ }^{-1}+9$ ton ha ${ }^{-1}$ & $2,39 a$ & 2,87 \\
\hline 0 ton $\mathrm{ha}^{-1}+12$ ton $\mathrm{ha}^{-1}$ & $3,20 \mathrm{ab}$ & 2,84 \\
\hline 2,5 ton $\mathrm{ha}^{-1}+0$ ton $\mathrm{ha}^{-1}$ & $2,89 a$ & 2,34 \\
\hline 2,5 ton $\mathrm{ha}^{-1}+3$ ton $\mathrm{ha}^{-1}$ & $3,60 \mathrm{abcd}$ & 3,19 \\
\hline 2,5 ton $\mathrm{ha}^{-1}+6$ ton $\mathrm{ha}^{-1}$ & $3,74 \mathrm{bcd}$ & 3,51 \\
\hline 2,5 ton $\mathrm{ha}^{-1}+9$ ton $\mathrm{ha}^{-1}$ & $3,61 \mathrm{abcd}$ & 3,82 \\
\hline 2,5 ton ha ${ }^{-1}+12$ ton $\mathrm{ha}^{-1}$ & $4,49 \mathrm{~cd}$ & 4,57 \\
\hline 5 ton ha ${ }^{-1}+0$ ton $\mathrm{ha}^{-1}$ & $3,88 \mathrm{bcd}$ & 2,86 \\
\hline 5 ton ha ${ }^{-1}+3$ ton $\mathrm{ha}^{-1}$ & $4,52 \mathrm{cde}$ & 3,14 \\
\hline 5 ton ha ${ }^{-1}+6$ ton ha ${ }^{-1}$ & $4,52 \mathrm{cde}$ & 3,36 \\
\hline 5 ton ha ${ }^{-1}+9$ ton ha ${ }^{-1}$ & 4,87 cde & 3,63 \\
\hline 5 ton ha ${ }^{-1}+12$ ton $\mathrm{ha}^{-1}$ & 5,77 cdef & 4,35 \\
\hline 7,5 ton ha ${ }^{-1}+0$ ton $\mathrm{ha}^{-1}$ & $3,58 a b c$ & 2,61 \\
\hline 7,5 ton $\mathrm{ha}^{-1}+3$ ton $\mathrm{ha}^{-1}$ & $4,37 \mathrm{~cd}$ & 2,85 \\
\hline 7,5 ton $\mathrm{ha}^{-1}+6$ ton $\mathrm{ha}^{-1}$ & $5,12 \mathrm{def}$ & 3,13 \\
\hline 7,5 ton ha ${ }^{-1}+9$ ton $\mathrm{ha}^{-1}$ & $5,36 \mathrm{def}$ & 3,78 \\
\hline 7,5 ton ha ${ }^{-1}+12$ ton $\mathrm{ha}^{-1}$ & 5,68defg & 4,19 \\
\hline 10 ton ha ${ }^{-1}+0$ ton $\mathrm{ha}^{-1}$ & $4,54 \mathrm{cde}$ & 2,93 \\
\hline 10 ton ha ${ }^{-1}+3$ ton $\mathrm{ha}^{-1}$ & 4,67 cde & 3,34 \\
\hline 10 ton ha ${ }^{-1}+6$ ton ha ${ }^{-1}$ & 4,69 cde & 3,95 \\
\hline 10 ton $\mathrm{ha}^{-1}+9$ ton $\mathrm{ha}^{-1}$ & 5,42 def & 4,55 \\
\hline 10 ton ha ${ }^{-1}+12$ ton $\mathrm{ha}^{-1}$ & 5,82 defg & 4,80 \\
\hline
\end{tabular}

Angka yang diikuti huruf yang sama tidak berbeda nyata pada taraf uji BNT 5\%

Pada penanaman dalam strip, walaupun pada taraf pupuk kandang dan mulsa yang sama nyata meningkatkan hasil jagung, tetapi hasil tersebut lebih rendah (3,91 dan 4,15 ton ha-1) dibanding penanaman menurut kontur. Sementara kombinasi perlakuan pada penanaman dalam strip tidak nyata meningkatkan hasil jagung. Hal ini diduga karena pada perlakuan penanaman dalam strip terjadi persaingan unsur hara antara jagung dengan strip rumput gajah. Hal ini terlihat dari penampilan (performance) strip rumput gajah yang tumbuh lebat dan hijau. Tala'ohu et al. 2003 [40] melaporkan bahwa kombinasi rorak dan strip lamtoro dengan mulsa atau pupuk kandang dapat memperbaiki pertumbuhan dan produksi jagung pipilan kering dibandingkan kebiasaan petani.

Kombinasi teknik konservasi tanah secara linier positif berpengaruh terhadap peningkatan hasil jagung pada penanaman menurut kontur (Gambar 1). Pengaruh pupuk kandang terhadap hasil jagung lebih tinggi. Hal ini terlihat dari nilai b $(0,24)$, walaupun nilai koefisien diskriminan $(R 2=0,86)$ lebih rendah dibanding pengaruh pemulsaan.Namun, hasil jagung justru sebesar 95\% dipengaruhi oleh pemberian mulsa dan hanya sebesar $5 \%$ dipengaruhi oleh faktor lainnya. Pada penanaman dalam strip (Gambar 2), pengaruh pupuk kandang justru lebih rendah dibanding pemulsaan yang tampak pada nilai b $(0,09)$ dan koefisien diskriminan $(R 2=0,66)$. Gambar 1. Interaksi antara Pupuk Kandang dan Mulsa terhadap hasil jagung pada Penanaman menurut KonturPengaruh pemulsaan pada perlakuan ini paling tinggi dengan nilai 
koefisien diskriminan (R2) sebesar 0,99. Dengan demikian, hasil jagung sebesar 99\% dipengaruhi oleh pemberian mulsa dan hanya sebesar $1 \%$ dipengaruhi oleh faktor lainnya.

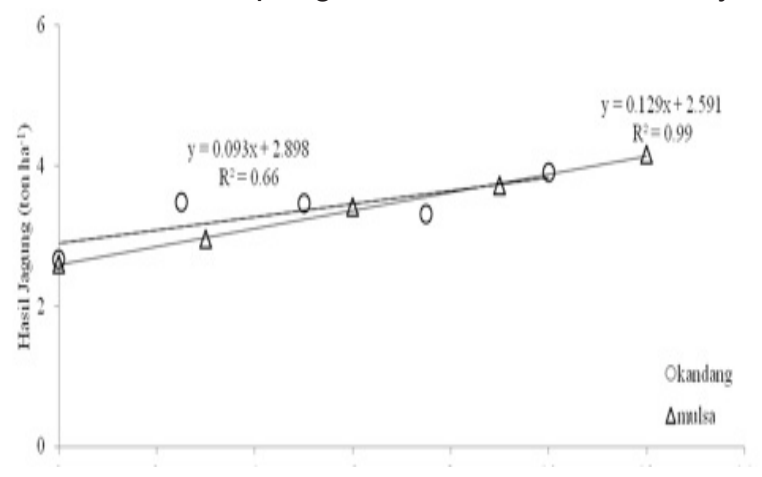

Gambar 1. Kombinasi teknik konservasi tanah secara linier positif berpengaruh terhadap peningkatan hasil jagung.
Berdasarkan kemiringan garis linier, maka hasil jagung dipengaruhi oleh pupuk kandang yang diberikan pada penanaman menurut kontur (nilai b 0,24) yang tertinggi dibanding pemberian mulsa, sebagaimana pernyataan Kasno et al. (2009) bahwa kemiringan garis linier salah satunya ditunjukkan oleh nilai b.

Dengan demikian, maka pada penanaman dalam strip hasil jagung dipengaruhi oleh pemulsaan karena nilai b paling tinggi dibanding pupuk kandang. Di samping itu, daerah ini cukup tinggi penguapannya sehingga dengan pemulsaan akan menekan laju penguapan dan pengaruhnya signifikan terhadap unsur hara yang mobil seperti nitrat (NO3-) dan Amonia (NH4+) karena proses volatilisasi [39]. Pemberian mulsa efektif menekan kehilangan hara karena pengangkutan oleh erosi dan aliran permukaan [3].

Tabel 3. Erosi tanah dan aliran permukaan akibat penerapan teknik konservasi tanah

\begin{tabular}{|c|c|c|c|}
\hline \multirow[b]{2}{*}{ Perlakuan Kombinasi } & Erosi Tanah & \multirow{2}{*}{$\begin{array}{l}\text { Tingkat } \\
\text { Bahaya } \\
\text { Erosi }\end{array}$} & \multirow{2}{*}{$\begin{array}{l}\text { Aliran Permukaan } \\
\mathrm{m}^{3} \text { ha }^{-1} \text { tahun }^{-1}\end{array}$} \\
\hline & $\begin{array}{l}\ldots \text { ton } \text { ha }^{-1} \text { tahun } \\
1 \ldots\end{array}$ & & \\
\hline $\begin{array}{llll}\begin{array}{l}\text { Penanaman menurut } \\
\text { kandang+mulsa }\end{array} & \text { kontur } & \text { +pupuk } \\
\end{array}$ & 1,34 & Sedang & 11,08 \\
\hline $\begin{array}{l}\text { Penanaman dalam strip+pupuk kandang } \\
+ \text { mulsa }\end{array}$ & 1,08 & Sedang & 9,55 \\
\hline Tanpa perlakuan (kebiasaan petani) & 108,11 & Berat & 153,02 \\
\hline
\end{tabular}

\subsection{PENGARUH TEKNIK KONSERVASI TANAH TERHADAP EROSI TANAH}

Hasil pengukuran erosi di lokasi penelitian pada penanaman menurut kontur lebih tinggi dibanding penanaman dalam strip (Tabel 4).Legowo (2005) melaporkan bahwa DAS Limboto berada pada kondisi kritis karena laju erosi tanah
44,69 ton ha-1 tahun-1 atau 3,72 mm tahun-1. Besarnya erosi tanah yang terjadi pada penanaman menurut kontur sebesar 1,34 ton ha-1 tahun-1. Sedangkan penanaman dalam strip erosi yang terjadi sebesar 1,08 ton ha-1 tahun-1. Walupun demikian, tingkat bahaya erosi yang terjadi masih tergolong sedang [5].

Tabel 4. Erosi tanah dugaan berdasarkan metode USLE

\begin{tabular}{|c|c|c|c|c|c|c|c|c|}
\hline \multirow{2}{*}{ Perlakuan } & \multicolumn{5}{|c|}{ Faktor } & Erosi Tanah $(\mathrm{A})$ & Rataan & \multirow{2}{*}{$\begin{array}{l}\text { TBE } \\
\text { (BRLKT 1986) }\end{array}$} \\
\hline & $\mathrm{R}$ & $\mathrm{K}$ & $\mathrm{C}$ & LS & $\mathrm{P}$ & ....... ton ha ${ }^{-1}$ tahun $^{-1}$ & $\ldots \ldots$ & \\
\hline $\mathrm{K} 0$ & 695 & 0,25 & 0,08 & 0,80 & 0,50 & 5,56 & \multirow{5}{*}{5,20} & \multirow{5}{*}{ Sedang } \\
\hline$\overline{\mathrm{K} 1}$ & 695 & 0,20 & 0,08 & 0,80 & 0,50 & 4,45 & & \\
\hline $\mathrm{K} 2$ & 695 & 0,27 & 0,08 & 0,80 & 0,50 & 6,00 & & \\
\hline K3 & 695 & 0,20 & 0,08 & 0,80 & 0,50 & 4,45 & & \\
\hline $\mathrm{K} 4$ & 695 & 0,25 & 0,08 & 0,80 & 0,50 & 5,56 & & \\
\hline S0 & 695 & 0,20 & 0,08 & 0,80 & 0,40 & 3,56 & \multirow{5}{*}{3,84} & \multirow{5}{*}{ Sedang } \\
\hline $\mathrm{S1}$ & 695 & 0,18 & 0,08 & 0,80 & 0,40 & 3,20 & & \\
\hline S2 & 695 & 0,20 & 0,08 & 0,80 & 0,40 & 3,56 & & \\
\hline S3 & 695 & 0,25 & 0,08 & 0,80 & 0,40 & 4,45 & & \\
\hline S4 & 695 & 0,25 & 0,08 & 0,80 & 0,40 & 4,45 & & \\
\hline $\mathrm{KP}$ & 695 & 0,27 & 1,00 & 0,80 & 1,00 & 150,09 & 150,09 & Sangat berat \\
\hline
\end{tabular}

Deposisisedimen sebesar 2,94 ton ha-1 tahun-1 atau $0,24 \mathrm{~mm}$ ha-1. Sedangkan hasil sedimen DAS Limboto adalah 41,75 ton ha- 1 tahun- 1 atau 3,48 mm tahun-1. Selanjutnya, Arsyad (2006) menyatakan bahwa keuntungan penanaman menurut kontur adalah terbentuknya penghambat aliran permukaan yang meningkatkan penyerapan air oleh tanah dan menghindari erosi tanah. 
Pada penanaman menurut strip, di samping diberikan mulsa juga ada tanaman strip yang dapat menekan laju erosi tanah. Suwardjo, 1978 [36] melaporkan bahwa penanaman jagung dengan pola strip hanya menghasilkan erosi tanah sebesar 2,6 ton ha-1 dibanding tanpa strip sebesar 4,6 ton ha-1. Selanjutnya, Utomo (1989) melaporkan bahwa penggunaan tanaman rumput gajah sebagai tanaman strip pada tanaman ubi kayu tumpangsari jagung dapat menekan laju erosi dari 55,10 ton ha-1 (tanpa strip) menjadi 37,15 ton ha-1. Dariah et. al (1993) menambahkan bahwa strip akar wangi (Vetiveria zizaniodes) yang ditanam pada budidaya tanaman jagung bisa menjadi tanaman konservasi, mudah dan murah. Erosi dugaan dengan metode USLE (Tabel 4) menunjukkan bahwa penanaman menurut kontur lebih tinggi (5,20 ton ha-1 tahun-1) dibanding penanaman dalam strip $(3,84$ ton ha-1 tahun- 1$)$.

Nilai erosi ini masih tergolong sedang berdasarkan tingkat bahaya erosi dan relatif sama dengan hasil pengukuran melalui petak erosi.Sementara itu, tingkat bahaya erosi pada lahan yang diusahakan petani tanpa tindakan konservasi tanah sudah tergolong sangat berat[5]. Berdasarkan nilai erosi yang dihasilkan, maka pengukuran langsung dengan petak erosi lebih sensitif dibanding pendugaan erosi dengan metode USLE. Beberapa komponen faktor sering tidak sesuai dengan kondisi lapangan dan masih bersifat umum [3], terutama faktor erosivitas hujan dan erodibilatas tanah. Oleh karena itu, usulan perbaikan keragaan metode ini untuk kondisi khusus terus dilakukan $[42,28]$.

Besarnya aliran permukaan pada penanaman menurut kontur lebih besar dibanding penanaman dalam strip (Tabel 4). Hal ini memberikan petunjuk bahwa pemulsaan lebih efektif menekan aliran permukaan pada penanaman dalam strip dibanding penanaman menurut kontur. BP2TPDAS-IBB (2002) melaporkan bahwa tanpa mulsa, aliran permukaan sebesar $45,3 \%$, infiltrasi sebesar $54,7 \%$ dan erosi 53,3 ton ha-1. Pemberian mulsa sebanyak 8,54 ton ha-1, aliran permukaan hanya $0,1 \%$, infiltrasi sebesar $99,5 \%$ dan erosi menjadi 0,0 ton ha-1. Pemberian pupuk kandang berpengaruh yang baik terhadap pemantapan agregat tanah, sehingga tidak mudah tererosi. Analisis tanah menunjukkan bahwa kemantapan agregat tanah di daerah ini sedang dengan struktur tanah gumpal, sehingga pemberian pupuk kandang meningkatkan kemantapan agregat tanah karena ada perekat oleh ikatan kompleks bahan organik tanah dan konsistensinya lebih teguh [31].

\section{KESIMPULAN}

Penerapan kombinasi teknik konservasi tanah pada penanaman menurut kontur nyata meningkatkan hasil jagung dam mampu menekan laju erosi tanah. Pada penanaman dalam strip, walaupun tidak nyata meningkatkan hasil jagung tetapi efektif menekan laju erosi tanah dibanding penanaman menurut kontur. Kombinasi perlakuan terbaik untuk hasil jagung tertinggi adalah pupuk kandang 10 ton ha-1 dan mulsa 12 ton ha-1. Sementara laju erosi tanah yang terjadi pada lahan jagung petani tanpa tindakan konservasi tanah sudah tergolong sangat berat, sehingga membutuhkan penanganan segera untuk menekan tingkat degradasi lahan yang lebih besar lagi. Berdasarkan nilai erosi yang terjadi, maka pengukuran langsung melalui petak erosi lebih sensitif hasilnya dibanding pendugaan erosi dengan metode USLE.

\section{DAFTAR PUSTAKA}

1. Anonim. 1982. Pedoman umum metode pengukuran erosi dalam rehabilitasi lahan kritis dan pencegahan erosi. Departemen Pertanian RI, Jakarta.

2. Adiningsih, J.S dan M. Sudjadi. 1993. Peranan sistem bertanam lorong (alley cropping) dalam meningkatkan kesuburan tanah pada lahan kering masam. Risalah Seminar hasil penelitian tanah dan agroklimat. Pusat penelitian tanah dan agroklimat, Bogor.

3. Arsyad S. 2006. Konservasi tanah dan air. Edisi revisi. Serial pustaka IPB Press, Bogor.

4. AbdurachmanA, A Dariah, dan A Mulyani. 2008. Strategi dan teknologi pengelolaan lahan kering mendukung pengadaan pangan nasional. J. Litbang Pertanian 27 (2): 43-49.

5. BRLKT. 1986. Petunjuk pelaksanaan rencana teknis lapangan rehabilitasi lahan dan konservasi tanah. Badan rehabilitasi lahan dan konservasi tanah Ditjend reboisasi dan rehabilitasi lahan Departemen kehutanan RI, Jakarta.

6. Bens O. W, N. A Buczko, U. Hüttl, R. F. 2001 Makroporositätund infiltrationseingescrafhten von Ackerböden unter differenzierter Bewirschraftung. Mitteilungen der Deutschen Bodenkundlichen Gesselschaft. Band 96, Heft 1.

7. BP2TPDAS-IBB. 2002. Pedoman praktik konservasi tanah dan air. Balai penelitian dan pengembangan teknologi pengelolaan daerah aliran sungai Indonesia bagian barat. Balitbang Kehutanan Departemen Kehutanan RI, Surakarta.

8. BPS. 2007. Provinsi gorontalo dalam angka tahun 2007. Badan pusat statistik Provinsi Gorontalo.

9. Dariah A, H. Suwardjo dan D. Erfandi. 1993. Akar wangi sebagai tanaman konservasi tanah dan air. Serial populer No.3. Puslittanak, Bogor. Hal 6-9.

10. Hudson N. 1971. Soil conservation. BT Brastford, London.

11. Havlin J.L, J.D Beaton, S.LTisdale, and W.L Nelson. 1999. Soil fertility and fertilizer An introduction to nutrient management. 6th ed. Prentice Hall. Upper Saddle River. New Jersey. pp.497.

12. Husain J. 2001. Wasserinfiltration in tonigen und strukturierten böden auf unterschiedlichen skalen und bei nutzungsänderung. Dissertation der fakultät 
für umweltwissenschaften und verfahrenstechnik der brandenburgischen technischen universität Cottbus, Deutsschland.

13. Husain J, H.H Gerke, and R.F Hüttl. 2001. Wasserinfiltration auf unterschiedlichen raumskalen in strukturierten böden. Mitteilungan der deutschen bodenkundlichen gesselschaft. 96 (1): 87-88.

14. Husain J, H.H Gerke, and R.F Hüttl. 2002. Infiltration measurements for determining effects of land use change on soil hydraulic properties in Indonesia. In Pagliai, M and Jones, R (Eds). Sustainable land management for enviromental protection-soil physics approach. advances in Geocology no. 32 catena verlag. Reiskirschen p.230-236.

15. Husain J, J.N Luntungan, Y. Kamagi, dan Nurdin. 2004. Model usahatani jagung berbasis konservasi di Provinsi Gorontalo. Laporan Hasil Penelitian badan penelitian dan pengengembangan dan pengendalian dampak lingkungan daerah (Balitbangpedalda) Provinsi Gorontalo, Gorontalo.

16. Faesal A. Najamuddin, dan M. Akil. 2006. Pengaruh cara pemberian dan takaran pupuk kandang terhadap hasil biomas tanaman jagung. J. penelitian pertanian tanaman pangan 25 (2): 124-128.

17. Joseph B. Th. 2005. Potensi sumberdaya tanah das limboto dan das randangan kabupaten gorontalo. Dalam prosiding seminar agropolitan komda Suluttenggo di Gorontalo, Gorontalo. Hal 12-15.

18. Kamagi Y. E. 1998. Pengaruh pengolahan tanah dan dosis pupuk kandang ayam pada tanah latosol berlereng terhadap erosi dengan tanaman kacang tanah sebagai indikator. J. solum 1 (3): 30-38.

19. Kurnia U, Sudirman, dan H. Kusnadi. 2005. Teknologi rehabilitasi dan reklamasi lahan. hlm. 147-182. Dalam teknologi pengelolaan lahan kering: menuju pertanian produktif dan ramah lingkungan. Pusat penelitian dan pengembangan tanah dan agroklimat, Bogor.

20. Kasno A. 2009. Respon tanaman jagung terhadap pemupukan Fospor pada Typic Dystrudept. J. tanah tropika. 14 (2) : 111-118.

21. LPTP. 1995. Paket budidaya jagung varietas arjuna di lahan kering. Agdex. 041/577 lembar informasi pertanian (LIPTAN) LPTP Koya Barat, Irian Jaya.

22. Lorenz G, C.L Bonelli, S. Roldan, C. Araya and K. Rondano. 2000. Soil quality change due to land use in a kastanozem-phaeozem soilscape of semiarid chaco. Mitteilungen der deustchen bodenkundlichen gesselschaft. Band 93.

23. Legowo, S.W.D. 2005. Pendugaan erosi dan sedimentasi dengan menggunakan model geowepp; studi kasus DAS Limboto, Provinsi Gorontalo. J. sumberdaya air 1 (1): 1-13.

24. Morgan R. P. C. 1988. Soil erosion and conservation. Longman group, Hongkong.

25. Nursyamsi D, A. Budiarto, dan L. Anggria. 2002. Pengelolaan kahat hara pada Inceptisol untuk meningkatkan pertumbuhan tanaman jagung. J. tanah dan iklim. 60:56-68.

26. Nurdin. 2005. Pertumbuhan dan produksi jagung (Zea mays L.) varitas lamuru yang dipupuk phonska dosis berbeda di Moodu Kecamatan Kota Timur Kota Gorontalo. J. eugenia. 11 : 396-400.
27. Nuraida L.N. 2006. Peningkatan kualitas tanah Ultisol Jasinga terdegradasi dengan pengolahan tanah dan pemberian bahan organik. Disertasi sekolah pascasarjana IPB, Bogor.

28. Renard K.G, G.R Foster, G.AWeesies, D.AMcCool, and D.C Yoder. 1997. Predicting soil erosion by wáter. A guide to conservation planning with the revised universal soil loss equation (RUSLE). Agric Handb. 703, US Govt print. office, Washington DC.

29. Rukmana R. 2001. Teknik pengelolaan lahan berbukit dan kritis. Kanisius, Yogyakarta.

30. Soepardi G. 1983. Sifat dan ciri tanah. Departemenilmu tanah fakultas pertanian IPB, Bogor.

31. Rachim D.A. 2007. Dasar-dasar genesis tanah. Departemen ilmu tanah dan sumberdaya lahan fakultas pertanianIPB, Bogor.

32. Staf Peneliti Pusat Penelitian Tanah. 1983. Term of referrence klasifikasi kesesuaian lahan. Proyek penelitian pertanian menunjang transmigrasi (P3MT) pusat penelitian tanah badan penelitian dan pengembangan pertanian departemen pertanian RI, Bogor.

33. Sarief S. E. 1986. Ilmu tanah pertanian. CV. Pustaka Buana, Bandung.

34. Sofiah. 1978. Petunjuk pelaksanaan percobaan erosi sistem petak kecil. Bahan penataran pps bidang ilmu tanah dan pemupukan II. Departemen pertanian RI, Jakarta.

35. Suwardjo. 1981. Peranan sisa-sisa tanaman dalam konservasi tanah dan air pada lahan usahatani tanaman semusim.Disertasifakultas pasca sarjana IPB, Bogor.

36. Suwardjo. 1987. Konservasi tanah. Penataran PPS bidang ilmutanah dan pemupukan II, 13 Maret-13 April 1987. Badan pengendali bimas dan lembaga penelitian tanah Departemen pertanian RI, Bogor.

37. Sanchez P. A. 1992. Sifat dan pengelolaan tanah tropika. ITB, Bandung.

38. Suriadikarta D.A, T. Prihatini, D. Setyorini, dan W. Hartatiek. 2002. Teknologi pengelolaan bahan organik tanah. hlm. 183-238. Dalam teknologi pengelolaan lahan kering menuju pertanian produktif dan ramah lingkungan. Pusat penelitian dan pengembangan tanah dan agroklimat, Bogor.

39. Tisdale S.L, W.L. Nelson and J.D. Beaton. 1990. Soil fertility and fertilizers. 4th edition. Macmillan Pub. Co., New York.

40. Tala'ohu S.H, Abas A, dan Kurnia, U. 2003. Optimalisasi produktivitas lahan kering beriklim kering melalui penerapan sistim usahatani konservasi. Dalam prosiding kongres nasional VIII himpunan ilmu tanah indonesia ( $\mathrm{HITI})$, Padang, 2123 Juli 2003. Hal 166-177.

41. Utomo W. H. 1989. Konservasi tanah di Indonesia; suatu rekaman dan analisa. Rajawali press, Jakarta.

42. Williams J.R. 1975. Sediment yield prediction with universal equation using runoff energy factors. In present and prospective technology for predicting sediment yields and source. USDA Agric research service, Southern region ARS-S-40: 244-252.

43. Weischmeier W.H dan D.D Smith .1978. Predicting rainfall erosion losses: a guide to conservation planning. USDA Handb. No 537: 58. 